\title{
Sustainability Reporting Practices: Evidence from Bangladesh
}

\author{
Sumaiya Akhter \\ Postgraduate student, Department of Accounting \& Information Systems \\ Jahangirnagar University, Savar, Dhaka, Bangladesh \\ E-mail: sumaiyatinaju@gmail.com \\ Pappu Kumar Dey (Corresponding author) \\ Assistant Professor, Department of Accounting \& Information Systems \\ Jahangirnagar University, Savar, Dhaka, Bangladesh \\ E-mail:pappudey@juniv.edu
}

Received: August 7, 2017

Accepted: August 17, 2017

Published: October 10, 2017

doi:10.5296/ijafr.v7i2.11659

URL: https://doi.org/10.5296/ijafr.v7i2.11659

\begin{abstract}
The objective of this paper is to examine the nature and extent of sustainability reporting practices by the listed companies in Bangladesh. In order to fulfill this objective, the research has examined the content analysis of annual report (2015-2016) and website of the top 50 listed companies (according to market capitalization). Based on Global Reporting Initiative (GRI) G4 guidelines, the study investigates three broad areas i.e. economic, environmental and social with 40 indicators. The findings of the study demonstrate that organizations in Bangladesh address few sustainability issues. Companies focus more on community development which is $90 \%$, followed by employment and employee benefits $(67 \%)$. The level of disclosures in website is meagre where only $26 \%$ of the sample companies disclose at least one indicator. Organizations' attention on issues like environment, human rights and product responsibility is limited in relation to other issues. The extent of disclosure is also poor that is $66 \%$ of the companies use less than 25 sentences in sustainability reporting. Moreover, only $16 \%$ of the sample companies use separate sustainability reporting section. The limited disclosures on sustainability issues may be because of voluntary sustainability reporting in Bangladesh.
\end{abstract}




\section{Macrothink}

International Journal of Accounting and Financial Reporting

Keywords: sustainability reporting, Bangladesh, Global Reporting Initiative (GRI), content analysis

\section{Introduction}

Corporate sustainability reporting has increasingly gained research attention among accounting and management researchers. The issue of global climate change has raised the community concerns about environment related issues and accelerated the societal expectations to social, economic and environmental matters (Hussain, Rowe and Quddus, 2012). Sustainability reporting has become an increasingly common practice by companies to fulfill the expectations and respond to the pressures and criticisms from stakeholders to inform them about the social and environmental impacts of business activities (Boiral, 2013). Sustainability issues mainly deal with the organization's voluntary activities such as public image with regard to economic, environmental, community, employee, human rights and other stakeholders' issues (Gray, Javad, Power and Sinclair, 2001). Earlier studies discover that the goal of sustainability reporting is to embrace the responsibility for the company's actions and encourage a positive impact through its activities on the environment, consumers, employees, communities, stakeholders and all other members of the society (Deegan and Blomquist, 2006; Gray et al., 2001; Gray, Kouhy and Lavers, 1995; Islam and Deegan, 2008). At present, companies face most pressing challenge in operating in an economically, socially and environmentally sustainable manner (Hopwood, Unerman and Fries, 2010). After declaration of new resolution titled 'Transforming our world: the 2030 Agenda for Sustainable Development' by UN, sustainable development is one of the main objectives all over the world (Ahmed, 2016). This agendum contains 17 goals known as sustainable development goals which reflect the scale and ambition of the global community seeking to realize human rights, gender equality and empowerment, sustainable management of water \& energy and to promote peaceful and inclusive societies for sustainable development. As Bangladesh has successfully attained Millennium Development Goals and is heading towards sustainable development goals for a sustainable future, sustainability reporting has an immense importance to address the issues and measuring the progress by how far the companies in Bangladesh are contributing for a sustainable future. Therefore, sustainability has become a matter of concern in Bangladesh. Given that the financial institutions are commanded towards moving sustainable development in the course of their influence as the providers of finance to businesses in other sectors of the economy, they can act as a major nexus in the aim of implementing the principles of sustainability in nations and communities as a whole (Khan, Islam, Fatima \& Ahmed, 2011). This has led to an earnest need to investigate the sustainability reporting practices by the companies in Bangladesh.

The aim of this study is to provide a comprehensive view of current sustainability reporting practices. In view of this objective, this study addressed to answer the following key questions:

- Do listed companies in Bangladesh practice sustainability reporting?

- If yes, then to what extent do sustainability reporting practices of Bangladeshi listed companies address sustainability issues voluntarily? 


\section{Mll Macrothink}

International Journal of Accounting and Financial Reporting

ISSN 2162-3082

2017, Vol. 7, No. 2

This is accomplished through a review of annual report and website of top 50 listed companies (according to market capitalization) in Bangladesh. Considering any specific industry would not reflect the situation of sustainability reporting practices by the companies. Though sustainability reporting is still in infancy stage in Bangladesh, considering top companies would help us assess the contribution of top companies towards sustainable development goals for a sustainable future. An evaluation of the current state of sustainability reporting in Bangladesh is vital for various reasons. Firstly, it will help identify the trends in sustainability reporting of companies in Bangladesh. Secondly, an analysis such as the proposed study will facilitate best practices with respect to the attainment of global sustainable development goals. Thirdly, it will contribute to the production of highly credible and effective sustainability reports and will encourage sustainability reporting. Finally, because of growing demand of disclosure on sustainability particularly with economic, environmental and social aspects this study will help identify improvement towards sustainability reporting. The study will contribute to the general body of knowledge through the presentation of key findings that highlight the present status of sustainability reporting and proffer measures for improvement of sustainability reporting in Bangladesh.

The remainder of the paper is organized as follows. A brief review of the relevant background information is provided in the section 2 . The research methodology is presented in Section 3. The analysis and findings part is in Section 4. Lastly conclusion has drawn in section 5 with a discussion for future research.

\section{Literature Review}

Sustainable development today appears to have captured the public and political imagination all over the world. The definition that has influenced sustainable development over the past two decades originated from the Brundtland report, which defined the goal of sustainable development to 'meet the needs of the present without compromising the ability of future generations to meet their own needs' (Brundtland, 1987). It has the potential to address fundamental challenges for humanity, now and into the future (Hopwood et al., 2005).

Sustainability reporting is a key tool to help an organization in setting goals measuring progress and managing sustainability. Reporting on organization's sustainability performance will give internal and external stakeholders a clear idea of its impact and can increase efficiency and improve performance. Companies may report on sustainability issues in a number of ways such as in their corporate websites, integrated with annual financial reporting or may produce stand-alone sustainability reports. The Global Reporting Initiative (GRI) provides guidance that is applicable to all sectors. It is the world's most widely used standard on sustainability as it enables business, government and individuals to make better decision based on the disclosures on the organizational sustainable development initiatives and process. Establishing in 1997, the first version of GRI was published in 2000 and second generation was unveiled at the world summit on sustainable development in 2002 at Johannesburg. The third versions, known as G3 published in 2006 and were updated to G3.1, expanding guidance on local community aspects, human rights and gender in 2011. Again, in 2010 GRI launched its fourth generation guideline known as G4. Recently in October 2016, 


\section{MInstitute Macrothink $^{m}$}

International Journal of Accounting and Financial Reporting

ISSN 2162-3082

2017, Vol. 7, No. 2

GRI published new version known as GRI Standards which will be effective after June 2018 (GRI, 2017). At the time of the data collection in this study (June 2017), the organization's G4 guidelines were in effect (GRI, 2017). The GRI-G4 performance disclosure indicators are organized into:

Economic: Disclosures on economic value generated and distributed, revenues, and infrastructure investments;

Environmental: Disclosures on impact on water, emissions, effluents, waste, biodiversity, and compliance with environmental laws; and

Social: Disclosures on human rights, labor practices, benefits, training, education, health, safety, diversity, equal opportunity, procurement practices with regard to anti-corruption and anti-trust practice, product responsibility, customer privacy and satisfaction etc.

The concept of sustainability is still very new in Bangladesh. Recently various agencies are creating considerable pressure on companies to act responsibly and be responsible for the impacts they have on social, political and ecological environments. According to Wiele, Kok, McKenna \& Brown (2001), there are expectations from the companies to participate in solving social problems, such as poverty and infrastructure. With a view to integrate sustainability, Bangladesh Bank (the central bank of Bangladesh) issued guidelines on 'Environmental Risk Management' (ERM) in 2011 which is updated on February 2017 titled as 'Environmental \& Social Risk Management (ESRM) for Banks and Financial Institutions in Bangladesh'. There is no guideline for other sectors except some laws for textile and chemical companies to ensure Effluent Treatment Plant (ETP) for their operations (Hussain, Rowe and Quddus, 2012). There have been a number of studies examining corporate social reporting in a developing country such as Bangladesh (Belal, 2000; Imam, 2000; Belal and Owen, 2007; Islam and Deegan, 2008; Mahmud, Biswas and Islam, 2017). Prior studies (Khan, Halabi and Samy, 2009; Mahmud et al., 2017) focused exclusively on banking sector. Social disclosure practices have evidently directed toward revealing the social disclosures status of banks with capturing a range of stakeholders' perceptions and the impacts of corporate governance elements on banks social reporting. Some studies (Belal, 2000; Imam, 2000; Dutta and Bose, 2007) also focused on other companies' practice of economic, social and environmental reporting and most of the studies produced almost similar results. The result reveals that sustainability related disclosures are disclosed by a few number of companies in Bangladesh and a synopsis of the studies are described below.

Imam (2000) examined the disclosures practices of 40 listed companies from the Dhaka Stock Exchange on social and environmental aspects. The findings reveal that $25 \%$ of companies made disclosures on community activities and $22.5 \%$ on environmental disclosures whereas only $10 \%$ companies disclose consumer related information. So it is evident that companies in Bangladesh disclose information in various aspects but most of the information is not adequate. Only $8.33 \%$ of the Bangladeshi companies address social and environmental issues in their corporate annual report on an average (Hossain, Islam and Andrew, 2006). Thus it is discernible that reporting on corporate website about social and environmental information by the listed companies in Bangladesh is still very low and 


\section{MInstitute ${ }^{m+1}$}

International Journal of Accounting and Financial Reporting

ISSN 2162-3082

multinational companies (MNCs) disclose corporate social and environmental information in the website more than local companies (Dutta and Bose, 2007)

The study of Sobhan, Amran and Zainuddin (2009) reveals that all companies disclosed at least one item related to HR followed by Community involvement by (47\%), consumer (23\%), environment (19\%), and others (18\%). Although 91\% made disclosures in at least one category, the level of environmental and climate change disclosures was very low. Disclosures were made in some selected and restricted categories only (Belal, Kabir, Cooper, Dey, Khan, Rahman and Ali, 2010).

According to the study of Khan et al. (2011), banks commitment towards decent works, labor practices and environmental items were found more than product responsibility and human rights and it has also been evidenced that banks addressed a small number of GRI G3 indicators. Banks propensity to follow financial sector specific (FSS) GRI guidelines are very low. Among sixteen (16) FSS and GRI only seven (7) items were disclosed by surveyed banks. That is to say, among the surveyed banks more than half of the financial sector specific disclosures were not reported in their annual reports. Only $41 \%$ of listed financial companies made some kind of CSR disclosure and the average length of disclosures amounted to less than half a page which indicates poor level of disclosures (Azim, Ahmed \& Netto, 2011).

Hossain et al. (2012) found that organizations in Bangladesh disclose more on community and pay limited attention to workplace/HR disclosure and environment. The banking and financial companies disclose more on social and environmental issues with compare to other sector organizations because of institutional pressure from central bank. They are also showing an emphasis on sustainability disclosure and being accountable to internal and external stakeholders for their action regarding governance, economic, environmental and social aspects including both positive and negative contributions, but still it is not satisfactory (Mahmud et al. 2017).

Based on the above analysis of literature, few works have been found on banking industry but no works have been found which analyze overall sustainable reporting practice by companies in Bangladesh. So to create awareness for sustainability issues and improve sustainable reporting practice in Bangladesh, this study aims to examine the sustainability reporting practices of top companies in Bangladesh.

\section{Research Methodology}

\subsection{Sample}

For this research, top 50 listed companies were selected on the basis of market capitalization from Dhaka Stock exchange (DSE). As there were 562 listed companies (as on 22 may 2017) (including mutual funds, debentures and treasury bonds) in DSE, top 50 companies is a standard sample as it represents approximate $10 \%$ of total companies and the selected companies represent nearly $40 \%$ of the total market capitalization. 


\section{Macrothink}

\subsection{Collection of Data and Analysis}

This study is empirical in nature based on secondary data. Corporate website and most recent annual report of the sample companies were considered for collecting data relating to sustainable reporting disclosures. Among 50 companies, annual report of 10 companies for the year 2016 was not available, so for those companies annual report of 2015 was used for the study. For analysis purpose, MS Excel was used to analyze data rather than using any sophisticated statistical software such as SPSS.

\subsection{Measurement of the Level of Sustainable Reporting}

In this study, content analysis technique was used to analyze sustainability related disclosures in the annual report and website. Based on GRI G4 guidelines, a checklist of 40 indicators was prepared to conduct the study and examine their sustainability reporting in three broad areas namely economic, environmental and social. Table 1 exhibits the indicator section headings along with number of indicators in each category.

Table 1. Indicator section headings and number of indicators under each major criterion

\begin{tabular}{|c|c|c|}
\hline \multicolumn{2}{|r|}{ Areas of disclosure } & No. of indicators \\
\hline \multicolumn{2}{|c|}{ 1. Economical } & 3 \\
\hline \multicolumn{2}{|c|}{ 2. Environmental } & 17 \\
\hline \multirow{4}{*}{ 3. Social } & Labor & 6 \\
\hline & Human rights & 4 \\
\hline & Society & 5 \\
\hline & Product responsibility & 5 \\
\hline & Total & 40 \\
\hline
\end{tabular}

To make the study more informative and resourceful, location of the reporting in the annual report and extent of reporting in terms of number of sentences were measured. To measure the reporting score dichotomous procedure developed by Cerf (1961) was used in this study.

- 1 was provided if an item was reported;

- 0 was provided if an item was not reported;

So, by reviewing annual reports, corporate websites and evaluating them from a transparency point of view, it might be revealed how well the reports fulfill the accounting law's intention of providing stockholders, customers and the society with better information on the company's approach to sustainability.

\section{Analysis \& Findings}

As mentioned earlier, identifying the areas and extent of sustainability reporting disclosures 


\section{Ml Macrothink}

International Journal of Accounting and Financial Reporting

ISSN 2162-3082

2017, Vol. 7, No. 2

by top listed companies in Bangladesh is one of our key research aims. To address this research question, a content analysis in view of the categorical variable (yes/no disclosure) was carried out. For this study our concentration is on sustainability issues such as economic, environmental, labor practices, human rights, product responsibility and social issues corresponding to the guidelines of GRI.

At first, the level of overall sustainability disclosures is measured through if the companies disclose at least one category in their annual report and corporate website. The overall sustainability disclosure profiles of companies are reported in Table 2. It shows that among 50 companies, 48 companies disclose sustainability disclosures in at least one category in their annual report. On the contrary, only 13 companies made such disclosure in their corporate website which is lower compared to annual report disclosure. It might be because of investors' unwillingness and poor computer literacy to internet usage in Bangladesh.

Table 2. Overall sustainability disclosures

\begin{tabular}{lcccc}
\hline \multicolumn{1}{c}{ Description } & Annual report & Percentage & Website & Percentage \\
\hline $\begin{array}{l}\text { Total companies with disclosures in at } \\
\text { least one category }\end{array}$ & 48 & $96 \%$ & 13 & $26 \%$ \\
\hline Total companies with no disclosures & 2 & $4 \%$ & 37 & $74 \%$ \\
\hline Total & 50 & $100 \%$ & 50 & $100 \%$ \\
\hline
\end{tabular}

To know the further insights in relation to companies' sustainability reporting, this study looks into the number of indicators disclosed by each company, which is presented in Table 3.

Table 3. Disclosure level in terms of number of indicators

\begin{tabular}{ccc}
\hline Number of indicators & No. of disclosing companies & Percentage \\
\hline Less than 10 indicators & 42 & $84 \%$ \\
\hline 10 to 20 indicators & 6 & $12 \%$ \\
\hline 21 to 30 indicators & 2 & $4 \%$ \\
\hline 31 to 40 indicators & 0 & $0 \%$ \\
\hline Total & 50 & $100 \%$ \\
\hline
\end{tabular}

It is apparent from the Table 3 that there is a depressing picture of sustainability reporting practice exists in companies in Bangladesh. $84 \%$ of companies disclose less than 10 indicators and $12 \%$ companies disclose 10 to 20 indicators whereas only $4 \%$ companies disclose 21 to 30 indicators, which indicate that sustainability reporting is still in initial stage in Bangladesh. Companies disclose only few areas in which they are bound to.

It was found from the study that the multinational pharmaceuticals companies and financial 


\section{Macrothink}

International Journal of Accounting and Financial Reporting

ISSN 2162-3082 2017, Vol. 7, No. 2

sectors among the top 50 have taken the lead in terms of score. The Acme Laboratories Bangladesh Ltd is a pioneer scoring 27 followed by Lanka Bangla Finance Ltd with a score of 21. However, financial and banking sectors practice average standard of sustainability reporting because of institutional pressure from central bank to report on social and environmental responsibility. Pharmaceuticals companies are seemed to have better sustainability reporting practice than other sectors which supports the study by Azim and Azam (2013), that listed pharmaceuticals companies practices some sort of social reporting to balance between stakeholders' reasonable expectations and running a successful business. Textile and clothing companies' disclosures are poor in accordance to GRI guideline although they are bound to maintain the international buyers' social and environmental compliance standard.

To measure disclosure practice by the companies in each area, Table 4 is prepared. It shows the disclosure level by the top 50 listed companies in Bangladesh in each category of GRI standard.

Table 4. Percentage of disclosing companies on specific issues

\begin{tabular}{lc}
\hline \multicolumn{1}{c}{ Areas of disclosure } & Percentage of disclosing companies \\
\hline Economic & $31.33 \%$ \\
\hline Environmental & $12.59 \%$ \\
\hline Labor & $36.67 \%$ \\
\hline Human rights & $4 \%$ \\
\hline Society & $20.4 \%$ \\
\hline Product responsibility & $4 \%$ \\
\hline
\end{tabular}

It is obvious that companies are intended to disclose on economic, labor and social aspects to create public image in the society and it is evident that $36.67 \%$ sample companies discloses on labor practices, $31.33 \%$ companies on economic aspects, $20.4 \%$ on societal aspects whereas there was an apparent scantiness of disclosure on product responsibilities $(2.4 \%)$ and human rights issues $(4 \%)$.

\subsection{Disclosures on Specific Issues}

From the table 5, it is evident that economic value generated by companies is disclosed by $44 \%$ of the companies whereas impact of infrastructure investments is disclosed by only $25 \%$ of the sample companies though the percentage is less than $50 \%$, it seems that companies are intended to disclose how much economic value they generated and distributed to show their performance to the society. 


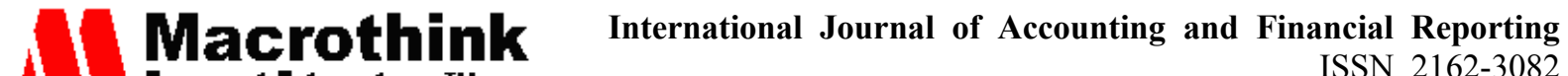

Table 5. Percentage of disclosures on economic issues

\begin{tabular}{lc}
\hline \multicolumn{1}{c}{ Economic Issues } & Percentage \\
\hline Economic value generated and distributed (EC1) & $44 \%$ \\
\hline Impact of infrastructure investments (EC3, EC7) & $25 \%$ \\
\hline
\end{tabular}

In the environment category, companies are reluctant to disclose information on the material, energy, water, GHG emission, waste and environmental investment. Table 6 reveals the disclosure level in environment issues which depicts a poor picture of disclosure on environmental issues. The level of disclosures is below $25 \%$ in each issue. Though some of the companies have environmental policy (in their annual report or website, the quality of information is not fair enough for potential stakeholders to judge the organizations ecological stand. To be more specific, banking and financial companies claim that they are moving towards to achieve green banking policy. Some of the bank and financial companies are financing bio gas plant and solar energy project (such as Brac bank 1td, Prime bank ltd etc.) and giving easy loan in these regard as prescribed by the central bank to boost investment in clean energy and to tackle the growing environmental concern. Although disclosure is not mandatory yet, the concern of government in environmental issues motivates the companies in addressing the issues.

Table 6. Percentage of disclosures on environmental issues

\begin{tabular}{lclc}
\hline \multicolumn{1}{c}{ Environmental Issues } & Percentage & \multicolumn{1}{c}{ Environmental Issues } & Percentage \\
\hline Materials $(\mathrm{EN} 1,2)$ & $20 \%$ & GHG emission $(\mathrm{EN} 15,16,17)$ & $7.33 \%$ \\
\hline Energy $(\mathrm{EN} 3,4,6)$ & $9.33 \%$ & Waste (EN23) & $24 \%$ \\
\hline Water $(\mathrm{EN} 8,9,10,22)$ & $2 \%$ & Environmental investment (EN31) & $20 \%$ \\
\hline
\end{tabular}

Among the three categories, social category is subdivided into four aspects such as labor, human rights, society and product responsibility. From Table 7 , it is obvious that $67 \%$ of sample companies disclose information about employment and benefits provided to the full time and part time employees, rates of new employee hired, which supports the study of Hossain et al. (2012). This is possibly for the reasons that organizations seek to attract resourceful employees and want to reduce employee turnover (Hossain et al., 2012).

But the information about employee health, safety and work related facilities are disclosed by only $6 \%$ the companies. Work related facilities like day care centre for the working mother are found by only one company (One Bank Ltd) among the 50 companies. No companies disclose about rate of injuries and accidents which indicates that they do not want to disclose any accidents or risk matter in their voluntary reporting. Employee training, education, programs for their skills management and lifelong learning are disclosed by $26.67 \%$ companies but the details of training hours, budget and percentage of employee trained are not mentioned by most of the companies. 
Table 7. Percentage of disclosures on social issues

\begin{tabular}{llc}
\hline & \multicolumn{1}{c}{ Social Issues } & Percentage \\
\hline \multirow{3}{*}{ Labor } & Employment and benefits (LA1, 2) & $67 \%$ \\
\cline { 2 - 3 } & Employees health and safety (LA6) & $6 \%$ \\
\cline { 2 - 3 } & Employees training and education (LA9, 10, 11) & $26.67 \%$ \\
\hline \multirow{2}{*}{ Human Rights } & Investments and procurement practices (HR1, 2) & $7 \%$ \\
\cline { 2 - 3 } & Non-discrimination (HR3) & $4 \%$ \\
\cline { 2 - 3 } Society & Trained security personnel (HR7) & $2 \%$ \\
\hline \multirow{2}{*}{$\begin{array}{l}\text { Product } \\
\text { responsibility }\end{array}$} & Community (SO1) & $90 \%$ \\
\cline { 2 - 3 } & Corruption (SO3, 4) & $9 \%$ \\
\hline
\end{tabular}

In the social issues, human rights and product responsibility category are seemed to be ignored by the companies. Disclosure level in the specific human rights issues is very low, only $7 \%$ disclose about investments and procurement practices, $4 \%$ on non-discrimination issues and $2 \%$ on trained security personnel on human rights issues. Thorough the study it is noticeable that companies are very much keen to disclose information on corporate social responsibility issues like community development programs, enlightening women and underprivileged people with education, donation to the prime minister relief fund, awarding scholarships to meritorious students etc. this society related information is more focused in the company's annual reports and website than other sustainability issues. To contribute in education, health and agriculture sector and to carry out social activities in a planned way some of the bank has established foundation (such as Exim Bank, Prime Bank etc.).

Though companies disclose more in society related issues, it is mostly confined into on their corporate social responsibility issues to gain customer favor and establish their brand image in the society. Other issues like corruption, training on anti-corruption policies, and legal action for anti-competitive behavior are neglected by most of the companies. Only $9 \%$ companies somehow disclose such information. Product responsibility issues are not addressed by most of the companies, more specifically they focus on the quality of their product and services to gain competitive advantage. Though some companies disclose information on product and service labeling (4\%), it is not satisfactory. Customer privacy and satisfaction is disclosed by only $1 \%$ of sample companies, which indicates that companies are unwilling to reveal such information to the stakeholders.

\subsection{Extent of Sustainability Disclosures}

The data in the Table 8 divulges the sample companies' number of sentences used in sustainability reporting. It is obvious from the table that most of the companies are not disclosing sustainability issues properly. Companies are only disclosing information which they are bound to disclose. It is found that companies on an average used 22 sentences to disclose sustainability issues. Maximum 108 sentences were found in Brac Bank Ltd's annual 


\section{Mll Macrothink}

International Journal of Accounting and Financial Reporting

ISSN 2162-3082

2017, Vol. 7, No. 2

report whereas no disclosure on sustainability issues was found in Fortune Shoes Company Limited's annual report as well as in website. 66\% of the companies are disclosing information in less than 25 sentences and only $4 \%$ of the companies disclose information more than 100 sentences. In terms of extent of disclosure, multinational companies and banking and financial companies are in primacy. Though textile and chemical companies are more vulnerable in terms of sustainability, they are lagging behind in disclosing sustainability issues properly.

Table 8. Number of sentences used in sustainability reporting

\begin{tabular}{ccc}
\hline Number of sentences & No. of companies & Percentage \\
\hline Less than 25 sentences & 33 & $66 \%$ \\
\hline 25 to 50 sentences & 10 & $20 \%$ \\
\hline 51 to 75 sentences & 5 & $10 \%$ \\
\hline 75 to 110 sentences & 2 & $4 \%$ \\
\hline Total & 50 & $100 \%$ \\
\hline
\end{tabular}

\subsection{Location of Sustainability Disclosures}

The analysis of the location of disclosing sustainability reporting issues in annual report of the top 50 listed companies in Bangladesh, it is found that most of the companies do not use any separate section for sustainability reporting and disclose information regarding sustainable issues in different locations or parts of the annual report.

Table 9. Location of sustainability disclosures

\begin{tabular}{lcc}
\hline Location & No. of companies & Percentage \\
\hline Value Added Statement & 22 & $44 \%$ \\
\hline Board Directors' Report & 18 & $36 \%$ \\
\hline Inventory Statement & 3 & $6 \%$ \\
\hline Sustainable/ Triple Bottom Line Reporting & 8 & $16 \%$ \\
\hline Corporate Information & 5 & $10 \%$ \\
\hline Strategic Business Unit & 1 & $2 \%$ \\
\hline Employment Report/ Human Resources & 6 & $12 \%$ \\
\hline Corporate Social Responsibility & 45 & $90 \%$ \\
\hline Qualitative Disclosure & 1 & $2 \%$ \\
\hline Notes & 38 & $76 \%$ \\
\hline
\end{tabular}

Table 9 shows different location of the annual report, in which companies address different sustainable issues. It is apparent that companies frequently disclose information in corporate 


\section{MInstitute Macrothink $_{\text {Int }}^{\text {Intis }}$}

International Journal of Accounting and Financial Reporting

social responsibility part, notes and in value added statement specifically $90 \%, 76 \%$ and $44 \%$ respectively. As sustainability regarding issues cover a number of issues and aspects, this information were found scattered in annual reports of most of the companies. Only $16 \%$ of companies use sustainable or triple bottom line reporting to disclose the sustainable issues. This 16\% includes multinational companies and banking and financial institutions.

As sustainability reporting is not mandatory yet, most of the Bangladeshi companies are merely care about reporting sustainability issues in a structured way. In absence of any specific format for sustainability reporting given by any regulatory body (e.g. Bangladesh Bank) companies in Bangladesh are seemed to be ignorant about disclosing the issues in schematic manner.

As the sustainability issues are not addressed in a structured manner, there remains question whether the sustainability reporting practiced by the companies are adequate to meet the increased expectations of the potential stakeholders and to judge the organizations sustainability performance.

\section{Conclusion}

Corporate sector is considered to be an integral part of the economy of Bangladesh. The need for involvement of corporate sector in sustainable development in Bangladesh is urgent and they can help by playing a meaningful and practical role for achieving sustainable development goals.

In this study, we investigate the sustainability reporting practices of the top 50 listed companies in Bangladesh through using GRI G4 standard. The study finds that sustainability reporting practices in Bangladesh is still in infancy stage and predominantly voluntary. Most of the companies emphasize to disclose about social issues more specifically their engagement with society and community development. Human rights, product responsibility and environmental issues are ignored comparatively with the labor practices, employee benefits, training and education issues. By examining the location and number of sentences to evaluate the nature and extent of disclosures it is found that most of the disclosures are positive and descriptive in nature. There is hardly any reference to negative news or difficulties faced by the companies in this regard. Certainly, implementing comprehensive sustainability reporting as imagined by the GRI framework is an immense undertaking, and one that the GRI itself acknowledges is achieved incrementally (GRI, 2006). The general understanding about sustainability disclosures in the context of a developing country is that companies operating in a developing country disclose social and environmental information only on a limited scale (Azim, Ahmed and Islam, 2009). Consistent with the findings from other developing countries, earlier research that focuses on Bangladesh shows that generally Bangladeshi companies disclose a limited amount of social and environmental information (Belal, 2000). However, this research used publicly available information such as company annual report (2015-2016), and company website. One of the limitations of this study is, it was bound by available information. Secondly, this study only considers top 50 listed companies based on market capitalization on a specific date it might change over time which could possibly change the trend of the sustainability reporting practices. 


\section{Macrothink}

International Journal of Accounting and Financial Reporting

In this study, we are not concerned about the quality of sustainability disclosures reported by companies. Since at the moment, there are no regulatory requirements for sustainability reporting issues in the context of Bangladesh, the information we explored in the study is not certified by independent assurance providers which may undermine the credibility of the disclosures. As our findings are based on the quantity of disclosures, it needs to be considered in the light of quality as well as quantity. However, managerial thoughts about sustainability reporting are not addressed in this study, further research is thus warranted to recognize perceptions of managers and stakeholder groups in relation to the possible adoption and reporting of the sustainability issues. For instance, data from content analysis (such as the findings from this study) can be combined with semi-structured interviewing of key personnel to not only understanding the underlying assumptions for voluntary sustainability disclosures but also investigate how to communicate more effectively with the relevant stakeholders.

\section{References}

Ahmed, H. U. (2016, December 6). Challenges to achieving Sustainable development goals in Bangladesh. The Financial Express. Retrieved from http://www.thefinancialexpress-bd.com/2016/12/06/55486/Challenges-to-achieving-Sustaina ble-Development-Goals-in-Bangladesh

Azim, M. I., \& Azam, S. (2013). Corporate sustainability reporting by pharmaceutical companies: Is it what it seems to be? Corporate Ownership and Control, 11(1), 767-778. Retrieved from http://www.virtusinterpress.org/IMG/pdf/COC_Volume_11_Issue_1_Fall_2013_Continued_. pdf

Azim, M. I., Ahmed, S., \& Islam, M. S. (2009). Corporate social reporting practice: evidence from listed companies in Bangladesh. Journal of Asia-Pacific Business, 10(2), 130-145. https://doi.org/10.1080/10599230902885556

Azim, M., Ahmed, E., \& D’Netto, B. (2011). Corporate social disclosure in Bangladesh: A study of the financial sector. International Review of Business Research Papers, 7(2), 37-55.http://hdl.cqu.edu.au/10018/91619

Belal, A. R. (2000). Environmental reporting in developing countries: empirical evidence from Bangladesh. Corporate Social-Responsibility and Environmental Management, 7(3), 114. https://doi.org/10.1002/1099-0925(200009)7:3<114::AID-EMA131>3.0.CO;2-E

Belal, A. R. (2001). A Study of Corporate Social Disclosures in Bangladesh. Managerial Auditing Journal, 16(5), 274-89. https://doi.org/10.1108/02686900110392922

Belal, A.R., Kabir, R., Cooper, S., Dey, P., Khan, A. N., Rahman, T., \& Ali, M. (2010). Corporate Environment and Climate Change Disclosures: Empirical Evidence from Bangladesh. Research in Accounting in Emerging Economies, 10, 145-167. https://doi.org/10.1108/S1479-3563(2010)0000010011

Belal, A.R., \& Owen, D.L. (2007). The Views of Corporate Managers on the Current State of 
and Future Prospects for Social Reporting in Bangladesh: An Engagement Based Study. Accounting, Auditing \& Accountability Journal, 20(3), 472-494. https://doi.org/10.1108/09513570710748599

Boiral, O. (2013). Sustainability reports as simulacra? A counter-account of A and A+ GRI reports. Accounting, Auditing \& Accountability Journal, 26(7), 1036-1071. https://doi.org/10.1108/AAAJ-04-2012-00998

Brundtland, G. H. (1987). World commission on environment and development (1987): Our common future. World Commission for Environment and Development. Oxford: Oxford University Press.

Cerf, A. R. (1961). Corporate Reporting and Investment Decision. Berkeley, CA: University of California Press.

Deegan, C., \& Blomquist, C. (2006). Stakeholder influence on corporate reporting: An exploration of the interaction between WWF-Australia and the Australian minerals industry. $\begin{array}{llll}\text { Accounting, } \quad \text { Organizations } & \text { Society, 31(4), 372. }\end{array}$ https://doi.org/10.1016/j.aos.2005.04.001

Dutta, P., \& Bose, S. (2007). Corporate Social and Environmental Reporting on corporate websites: a study on listed companies of Bangladesh. The Cost \& Management, 35(4), 31-49. Retrieved

from https://www.researchgate.net/profile/Sudipta_Bose2/publication/228285456.pdf

Gray, R., Javad, M., Power, D. M., \& Sinclair, C. D. (2001), Social and Environmental Disclosure and Corporate Characteristics: A Research Note and Extension. Journal of Business Finance \& Accounting, 28, 327-356. https://doi.10.1111/1468-5957.00376

Gray, R., Kouhy, R., \& Lavers, S. (1995). Corporate social and environmental reporting: a review of the literature and a longitudinal study of UK disclosure. Accounting, Auditing \& Accountability Journal, 8(2), 47-77. https://doi.org/10.1108/09513579510146996

GRI. (2006). Sustainability Reporting Guidelines. Boston: Global Reporting Initiative. Retrieved May 23, 2017, from https://www.globalreporting.org/

GRI. (2017). About Sustainability Reporting. Retrieved June 13, 2017, from https://www.globalreporting .org/information/sustainability-reporting/Pages/default.aspx

Hopwood, A. G., Unerman, J., \& Fries, J. (2010). Accounting for sustainability: Practical insights. Earthscan.

Hopwood, B., Mellor, M., \& O'Brien, G. (2005). Sustainable development: mapping different approaches. Sustainable Development, 13(1), 38-52. https//doi/10.1002/sd.244.

Hossain, M., Islam, K., \& Andrew, J. (2006). Corporate social and environmental disclosure in developing countries: Evidence from Bangladesh. Retrieved from http://ro.uow.edu.au/cgi/viewcontent.cgi?article=1194\&context=commpapers

Hossain, M.M., Rowe, A., \& Quaddus, M. (2012). The Current Trends of Corporate Social 


\section{Macrothink}

International Journal of Accounting and Financial Reporting ISSN 2162-3082 2017, Vol. 7, No. 2

and Environmental Reporting (CSER) in Bangladesh. Retrieved from http://researchrepository.murdoch.edu

Imam, S. (2000). Corporate social performance reporting in Bangladesh. Managerial Auditing Journal, 15(3), 133-142. http://dx.doi.org/10.1108/02686900010319384

Islam, M. A., \& Deegan, C. (2008). Motivations for an organization within a developing country to report social responsibility information: Evidence from Bangladesh. Accounting, Auditing \& Accountability Journal 21(6), 850-874, https://doi.org/10.1108/0951357081

Khan, H. U. Z., Halabi, A. K., \& Samy, M. (2009). Corporate social responsibility (CSR) reporting: a study of selected banking companies in Bangladesh. Social Responsibility Journal, 5(3), 344-357. https://doi.org/10.1108/17471110910977276

Khan, H. U. Z., Islam, M.A., Fatima, J. K., \& Ahmed, K. (2011). Corporate sustainability reporting of major commercial banks in line with GRI: Bangladesh evidence. Social Responsibility Journal, 7(3), 347-362. https://doi.org/10.1108/17471111111154509

Mahmud, S., Biswas, T., \& Islam, N. (2017). Sustainability Reporting Practices and Implications of Banking Sector of Bangladesh according to Global Reporting Initiative (GRI) framework: An Empirical Evaluation. International Journal of Business and Management Invention, 6(3), 1-14. Retrieved from http://www.ijbmi.org

Sobhani, F. A., Amran, A., \& Zainuddin, Y. (2009). Revisiting the practices of corporate social and environmental disclosure in Bangladesh. Corporate Social Responsibility and Environmental Management, 16(3), 167-183. https://doi.org/10.1002/csr.193/full

Wiele, T., Kok, P., McKenna, R., \& Brown, A. (2001). A corporate social responsibility audit within a quality management framework. Journal of Business Ethics, 31(4), 285-297. https://link.springer.com/article/10.1023/A:1010767001610

\section{Appendices}

Appendix 1. Selected companies based on market capitalization (as on 22 may, 2017)

$\begin{array}{cl}\text { Rank } & \text { Company Name } \\ 1 & \text { IFAD Autos Ltd } \\ 2 & \text { Agni Systems Ltd } \\ 3 & \text { United Power Generations and Distribution Company Ltd } \\ 4 & \text { DOREEN Power Generations and Systems Ltd } \\ 5 & \text { ACI Limited } \\ 6 & \text { Bangladesh Shipping Corporation } \\ 7 & \text { Paramount Textile Limited } \\ 8 & \text { BDCOM Online Ltd } \\ 9 & \text { Evince Textile Ltd } \\ 10 & \text { Lanka Bangla Finance Ltd } \\ 11 & \text { MJL Bangladesh Limited }\end{array}$




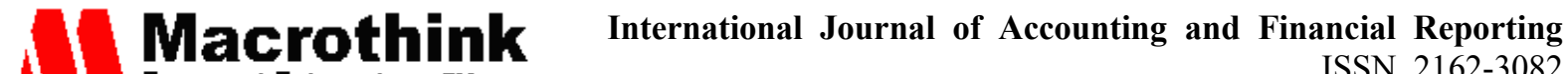

12 Barka Power Ltd

13 AAMRA Technologies Limited

14 Shahjibazar Power Co.Ltd

15 FAS Finance and Investment Limited

16 Beximco Pharmaceuticals Ltd

17 One Bank Ltd

18 Regent textile

19 RSRMSteel

20 Bangladesh Finance and Investment Co. Ltd

21 Argon Denims Limited

22 Brac bank Limited

23 Intech Limited

$24 \quad$ National Feed Mill Ltd

25 Miracle Industries Limited

26 Tung Hai Knitting \& Dyeing Ltd

27 Bangladesh Export Import Company Ltd

28 Square PharmaceuticalsLtd

29 National Bank Ltd

$30 \quad$ SAIF Power tec Ltd

31 Mercantile bank Ltd

32 City Bank LTD

33 central pharmaceuticals ltd

34 CMC Kamal Textile Ltd

35 First Security Islami Bank Ld

36 Prime Bank Ltd

37 Fortune

38 Exim Bank Limited

39 Far Chemical Industries Ltd

40 Confidence Cement Ltd

41 Islamic Finance\& Investment Ltd

42 Mozaffar Hossain Spinning Mills Ltd

43 Bangladesh Building Systems Ltd

$44 \quad$ Islami Bank Ltd

45 Heidelberg Cement Bangladesh Ltd

46 Linde Bangladesh Limited

47 Active Fine Chemicals Ltd

48 Sonali Aansh Industries Limited

49 Appollo Ispat Complex Ltd

50 ACME Laboratories Ltd 


\section{Ml Macrothink \\ International Journal of Accounting and Financial Reporting

Appendix 2. Checklist of GRI 40 Indicators

\begin{tabular}{|c|c|}
\hline Serial & Code \\
\hline 1 & EC-1 \\
\hline 2 & EC-3 \\
\hline \multicolumn{2}{|l|}{3} \\
\hline & EC-7 \\
\hline 4 & EN-1 \\
\hline 5 & EN-2 \\
\hline 6 & EN-3 \\
\hline 7 & EN-4 \\
\hline 8 & EN-6 \\
\hline 9 & EN-8 \\
\hline 10 & EN-9 \\
\hline 11 & EN-1 \\
\hline 12 & EN-12 \\
\hline
\end{tabular}

13 EN-15 Direct greenhouse gas (GHG) emissions (scope 1)

14 EN-16 Energy indirect greenhouse gas (GHG) emissions

15 EN-17 Other indirect greenhouse gas (GHG) emissions

16 EN-22 Total water discharge by quality and destination

17 EN-23 Total weight of waste by type and disposal method

18 EN-27 Extent of impact mitigation of environment impacts of products and services

19 EN-28 Percentage of products sold and their packaging materials that are reclaimed by category

20 EN-31 Total environmental protection expenditures and investments by type

21 LA-1 Total number and rates of new employee hires and employee turnover by age group, gender and region

22 LA-2 Benefits provided to full-time employees that are not provided to temporary or part-time employees, by significant locations of operation

23 LA-6 Type of injury and rates of injury, occupational diseases, lost days, and absenteeism, and total number of work-related fatalities, by region and by gender.

24 LA-9 Average hours of training per year per employee by gender, and by employee category

25 LA-10 Programs for skills management and lifelong learning that support the continued employability of employees and assist them in managing career endings

26 LA-11 Percentage of employees receiving regular performance and career development reviews, by gender and by employee category

27 HR-1 Total number and percentage of significant investment agreements and 
28 HR-2 Total hours of employee training on human rights policies or procedures concerning aspects of human rights that are relevant to operations, including the percentage of employees trained

29 HR-3 Total number of incidents of discrimination and corrective actions taken

30 HR-7 Percentage of security personnel trained in the organization's human rights policies or procedures that are relevant to operations

31 SO-1 Percentage of operations with implemented local community engagement, impact assessments, and development programs

32 SO-3 Total number and percentage of operations assessed for risks related to corruption and the significant risks identified.

33 SO-4 Communication and training on anti-corruption policies and procedures

34 SO-6 Total value of political contributions by country and recipient/beneficiary

35 SO-7 Total number of legal actions for anti-competitive behavior, anti-trust, and monopoly practices and their outcomes

36 PR-3 Type of product and service information required by the organization's procedures for product and service information and labeling, and percentage of significant product and service categories subject to such information requirements

37 PR-4 Total number of incidents of non-compliance with regulations and voluntary codes concerning product and service information and labeling, by type of outcomes

38 PR-5 Results of surveys measuring customer satisfaction

39 PR-7 Total number of incidents of non-compliance with regulations and voluntary codes concerning marketing communications, including advertising, promotion, and sponsorship, by type of outcomes

40 PR-8 Total number of substantiated complaints regarding breaches of customer privacy and losses of customer data.

\section{Copyright Disclaimer}

Copyright for this article is retained by the author(s), with first publication rights granted to the journal.

This is an open-access article distributed under the terms and conditions of the Creative Commons Attribution license (http://creativecommons.org/licenses/by/4.0/) 